\title{
Rapid and Sensitive Voltammetric Determination of Aclonifen in Water Samples
}

\section{Dariusz Guziejewski, ${ }^{1} *$ Sylwia Smarzewska, ${ }^{1}$ Monika Skowron, ${ }^{1}$ Witold Ciesielski, ${ }^{1}$ Agnieszka Nosal-Wiercińska ${ }^{2}$ and Sławomira Skrzypek ${ }^{1}$}

\author{
${ }^{1}$ Department of Inorganic and Analytical Chemistry, University of Lodz, Lodz, Poland \\ ${ }^{2}$ Department of Analytical Chemistry and Instrumental Analysis, Maria Curie-Sktodowska University, Lublin, Poland \\ * Corresponding author: E-mail: dguziejewski@uni.lodz.pl \\ Tel.: +48(42)6355480; Fax: +48(42)6355808
}

Received: 01-05-2014

\begin{abstract}
This paper presents the use of square wave voltammetry (SWV) and square wave adsorptive stripping voltammetry (SWAdSV) in conjunction with a cyclic renewable silver amalgam film electrode $(\mathrm{Hg}(\mathrm{Ag}) \mathrm{FE})$ for the determination of aclonifen in spiked water samples. A reduction peak at $-0.65 \mathrm{~V}$ versus $\mathrm{Ag} / \mathrm{AgCl}$ was obtained in the selected buffer (borax buffer with $\mathrm{pH}$ 9.2), exhibiting the characteristics of an irreversible reaction. The effect of square wave (SW) frequency, SW amplitude and step potential, as well as accumulation parameters (time and potential) were studied to select the optimal experimental conditions. The calibration curve was linear in the aclonifen concentration range from $1.0 \times$ $10^{-7}$ to $1.0 \times 10^{-6} \mathrm{~mol} \mathrm{~L}^{-1}$ and from $1.0 \times 10^{-8}$ to $1.0 \times 10^{-7} \mathrm{~mol} \mathrm{~L}^{-1}$ for SWV and SWAdSV, respectively. The detection and quantification limits were found to be $3.1 \times 10^{-8} \mathrm{~mol} \mathrm{~L}^{-1} ; 1.0 \times 10^{-7} \mathrm{~mol} \mathrm{~L}^{-1}$ and $2.9 \times 10^{-9} \mathrm{~mol} \mathrm{~L}^{-1} ; 9.6 \times 10^{-9} \mathrm{~mol}^{-1}$ $\mathrm{L}^{-1}$ for SWV and SWAdSV, respectively. The proposed method was applied successfully in the determination of aclonifen in spiked water samples. The developed procedure can be adequate at least for screening purposes, where positive results should be confirmed by more selective method.
\end{abstract}

Keywords: Aclonifen determination; silver amalgam film electrode; square wave voltammetry; herbicide

\section{Introduction}

Herbicides are used globally to eliminate weeds. Even after one application, they can be absorbed by the plant or deposited on the soil surface. These processes are strongly dependent on the type of herbicide, crop, soil, application method, and climatic conditions. Thus, nowadays, there is a growing emphasis on the development of analytical methods for determination of herbicides due to their toxicity. ${ }^{1,2}$

Aclonifen (Scheme 1) is a diphenylether herbicide used in the preemergence control of broad-leaved and grass weeds in sunflower cultivation around the world. ${ }^{3,4}$<smiles>Nc1c([N+](=O)[O-])ccc(Oc2ccccc2)c1Cl</smiles>

Scheme 1. Chemical structure of aclonifen (2-chloro-6-nitro-3-phenoxyaniline).
The mode of action is based on inhibition of chlorophyll ${ }^{5,6}$ and carotenoid synthesis ${ }^{7}$ causing large foliar necroses. ${ }^{8}$ Aclonifen is a moderately hazardous herbicide. Pursuant to the directive of the European Union Commission from 15.12.2008, aclonifen was approved for use since 08.01.2009. Higher concentrations may cause skin irritation or renal and hepatic function disorders after prolonged exposure. The use of this particular herbicide entails a huge risk for aquatic organisms as well. ${ }^{9}$ As aclonifen is stable in aqueous media and soil, the likelihood of accumulation is very high. Degradation time varies from 15.4 to 16.1 days, ${ }^{10}$ but an exposure of only $96 \mathrm{~h}$ is sufficient to curb the growth of algae and cause fish death. ${ }^{9}$

Aclonifen is usually analyzed with gas ${ }^{11}$ or liquid chromatography, ${ }^{12}$ often in combination with mass spectrometry. ${ }^{13}$ Several electrochemical ${ }^{14-16}$ methods have been developed for herbicide determination. Zaouak and coworkers ${ }^{14}$ as well as Inam and Cakmak ${ }^{15}$ investigated aclonifen electrochemical oxidation processes and its determination on a glassy carbon electrode. Achieved limits of 
detection were only 0.6 and $0.07 \mathrm{mg} \mathrm{L}^{-1}$, respectively, while Novotny and Barek used differential pulse voltammetry and reduction peak with detection limit $2 \mu \mathrm{mol} \mathrm{L}^{-1}{ }^{16}$

While the methods based on high performance liquid chromatography and/or spectrometry are obviously both sensitive and selective, they are also financially and instrumentally demanding and rather time consuming. On the other hand, modern voltammetric techniques are inexpensive, sensitive, and fast, and thus applicable for wide-scale monitoring of electrochemically active pollutants. Although a mercury electrode is clearly the best choice for electroanalytical determination of aclonifen, there is a tendency to replace liquid mercury electrodes with other non-toxic materials, e.g., bismuth or solid amalgam electrodes, due to strict safety and ecological rules. An example of such an electrode is a renewable silver amalgam film electrode $(\mathrm{Hg}(\mathrm{Ag}) \mathrm{FE}),{ }^{17-20}$ which properties, such as a wide potential window, easily mechanically renewable surface, and low noise, make it a very promising electroanalytical tool. Liquid amalgam, with a volume not exceeding $10 \mu \mathrm{L}$, enables stable electrode functioning for several months. A $\mathrm{Hg}(\mathrm{Ag}) \mathrm{FE}$ has been successfully applied in quantitative analysis of various elements and organic compounds. ${ }^{21-24}$ This paper presents mechanistic studies and quantitative determination of aclonifen.

\section{Materials and Methods}

\section{1. General Voltammetric Procedure, Instrumentation and Software}

All voltammetric experiments were carried out using a $\mu$ Autolab Type III (Eco Chemie, Netherlands) with GPES software (General Purpose Electrochemical System, version 4.9). A classical three-electrode system consisting of a reference electrode $\left(\mathrm{Ag} / \mathrm{AgCl}-3 \mathrm{~mol} \mathrm{~L}^{-1}\right.$ $\mathrm{KCl}$ ), a counter electrode (Pt wire), and a working electrode (a renewable silver amalgam film electrode from mtm-anko, Cracow, Poland) was used. The construction details and properties of the $\mathrm{Hg}(\mathrm{Ag}) \mathrm{FE}$ have been described previously. ${ }^{17}$

Quantitative measurements were performed using SWV or SWAdSV and the standard addition procedure. The reported signals are based on peak currents measured after subtraction of the blank. The amalgam film of the $\mathrm{Hg}(\mathrm{Ag}) \mathrm{FE}$ electrode was refreshed before each measurement. A potential of $-0.9 \mathrm{~V}$ was applied to condition the electrode after the refreshing step. In SWAdSV experiments, during the accumulation step, a potential of $-0.2 \mathrm{~V}$ was applied with the solution being stirred. After the accumulation period, the solution was equilibrated for $5 \mathrm{~s}$. Subsequently, a voltammogram for the blank was recor$\mathrm{ded}$, and the required volumes of the compound were added. Measurements were carried out in deaerated solutions. The optimal results for SW experiments were obtai- ned in borax buffer at pH 9.2, SW amplitude $E_{\mathrm{sw}}=50 \mathrm{mV}$, step potential $\Delta E=5 \mathrm{mV}$, frequency $f=150 \mathrm{~Hz}$. For adsorptive stripping voltammetry measurements accumulation time $t_{\mathrm{acc}}=45 \mathrm{~s}$, and accumulation potential $E_{\mathrm{acc}}=$ $-0.2 \mathrm{~V}$ were selected. All electrochemical measurements were carried out at the ambient temperature of the laboratory.

Spiked water solutions were prepared as follows: $1 \mathrm{~mL}$ of $1.0 \times 10^{-5} \mathrm{~mol} \mathrm{~L}^{-1}$ aclonifen solution was transferred to a $25 \mathrm{~mL}$ flask and filled to volume with tap or river water. In voltammetric experiments, the supporting electrolyte contained $1 \mathrm{~mL}$ of (spiked tap/river) water solution and $9 \mathrm{~mL}$ of borax buffer with $\mathrm{pH}$ 9.2. The aclonifen concentration in spiked samples was analyzed using the standard addition method. Each addition contained 0.4 nmol of herbicide. Voltammograms were recorded after each addition. Recoveries were calculated after six replicate experiments.

\section{2. Solutions and Materials}

An aclonifen standard was purchased from Dr Ehrenstorfer (Augsburg, Germany). The supporting electrolytes were $0.04 \mathrm{M}$ Britton-Robinson (BR), $0.2 \mathrm{M}$ borax, and $0.2 \mathrm{M}$ borate buffers. All the chemicals used for the preparation of buffer solutions were from POCH S.A. (Gliwice, Poland). Fresh stock solution $\left(1.00 \times 10^{-3} \mathrm{~mol}\right.$ $\mathrm{L}^{-1}$ ) was prepared weekly by dissolving $6.62 \mathrm{mg}$ of aclonifen in $5 \mathrm{~mL}$ of ethanol (storage in dark and cool place if not in use). This concentrated solution was transferred to a $25 \mathrm{~mL}$ flask and filled to volume with water which had been demineralized in a PURALAB UHQ (Elga LabWater, UK).

\section{Results and Discussion}

\section{1. Electrochemical Behavior of Aclonifen and the Influence of $\mathrm{pH}$ and SW Parameters}

Generally, $\mathrm{pH}$ is one of the factors that strongly influence the shape of recorded voltammograms, and it is important to test the effect of supporting electrolyte $\mathrm{pH}$ on electrochemical systems. The impact of the medium was evaluated using $0.04 \mathrm{~mol} \mathrm{~L}^{-1}$ Britton-Robinson buffers ( $\mathrm{pH}$ $2.0-10.0$ ) with $5 \times 10^{-7} \mathrm{~mol} \mathrm{~L}^{-1}$ aclonifen solution. Fig. 1 illustrates the influence of BR buffer $\mathrm{pH}$ on aclonifen peak current $I_{\mathrm{p}}$ and potential $E_{\mathrm{p}}$. With increasing $\mathrm{pH}$, the aclonifen signal rises and shifts towards more negative potentials. As it can be seen from the inset in Figure 1, the plot of $E_{p}$ versus $\mathrm{pH}$ is linear across the entire examined range.

The slope of the plot $(0.059 \mathrm{~V})$ is identical to the theoretical value, so it can be assumed that the examined signal indicates a process in which equal numbers of protons and electrons are involved (the slope of the same re- 


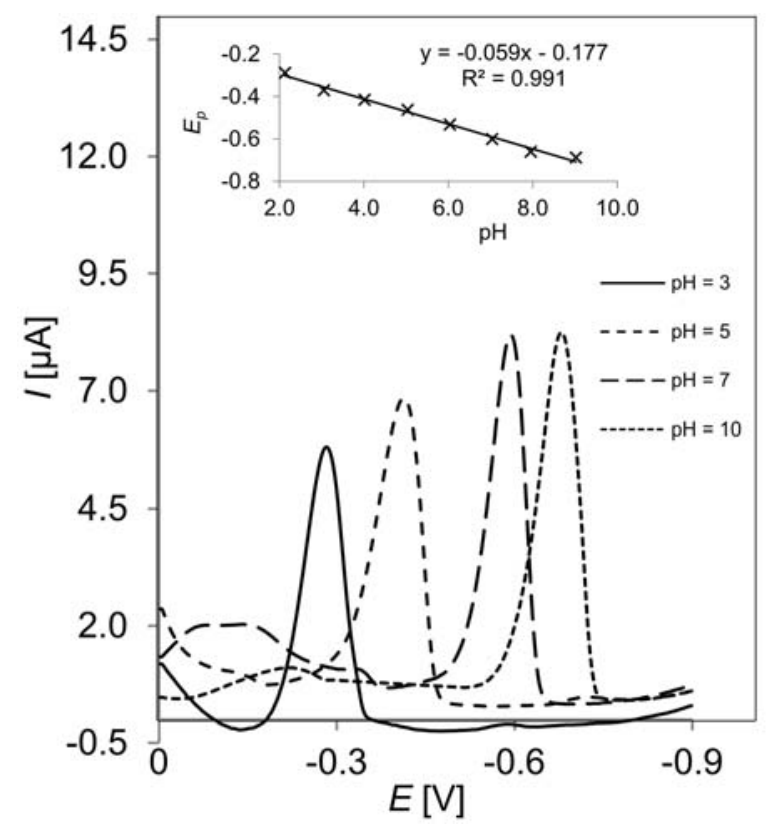

Figure 1. Voltammograms of $5 \times 10^{-7} \mathrm{~mol} \mathrm{~L}^{-1}$ aclonifen solution recorded in BR buffers with the following experimental conditions: $\mathrm{SW}$ amplitude $E_{\mathrm{sw}}=25 \mathrm{mV}, \Delta E=5 \mathrm{mV}, f=50 \mathrm{~Hz}$; Inset: relationship between $\mathrm{pH}$ and aclonifen peak potential.

lationship obtained for the second signal was equal to 0.06 V). As the highest aclonifen signals were observed in an alkaline medium, other supporting electrolytes were also examined (borax and borate buffers). Finally, borax buffer with $\mathrm{pH} 9.2$ was chosen for further studies due to the best

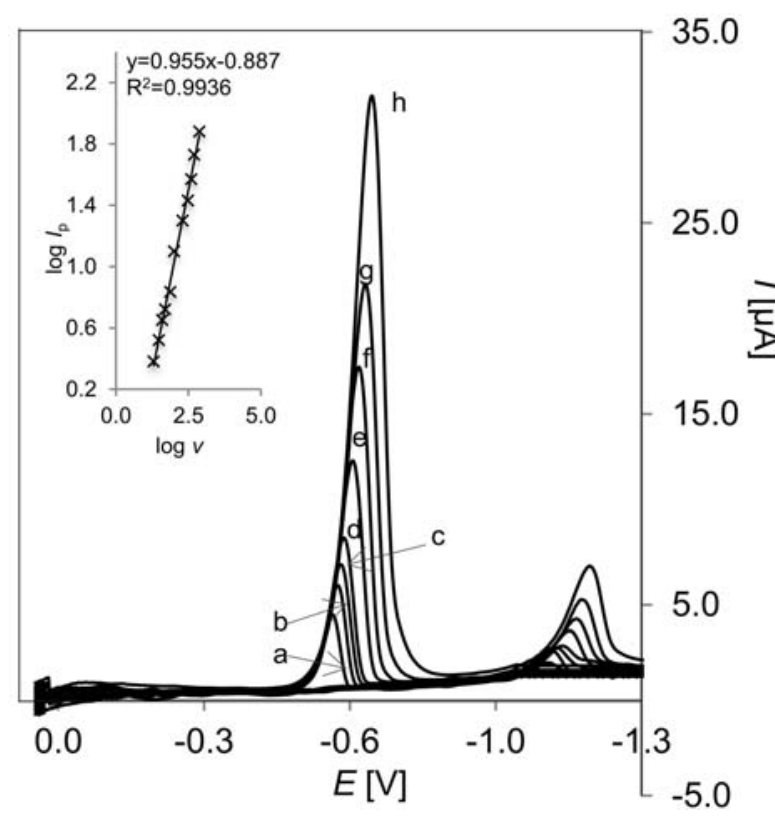

Figure 2. Cyclic voltammograms for $1 \times 10^{-5} \mathrm{~mol} \mathrm{~L}^{-1}$ aclonifen solution in borax buffer ( $\mathrm{pH} 9.2$ ) at various scan rates: (a) 30, (b) 50, (c) 75, (d) 100, (e) 200, (f) 300, (g) 500, and (h) $700 \mathrm{mV} \mathrm{s}^{-1}$; inset: the linear relationship between the $\log$ peak current $I_{\mathrm{p}}$ and $\log$ scan rate $v$ for the first peak $\left(E_{p}=-0.65 \mathrm{~V}\right)$. peak shape and maximum current value. The influence of the ionic strength of the supporting electrolyte was also examined. The ionic strength was varied with changing borax buffer content (from 5 to $100 \%, \% \mathrm{v}$ ) in the supporting electrolyte. On the basis of these results, the supporting electrolyte chosen for further studies contained $50 \%$ borax buffer and $50 \%$ water.

Two reduction peaks are visible in Figure 2, which presents preliminary cyclic voltammetric experiments carried out with a $\mathrm{Hg}(\mathrm{Ag}) \mathrm{FE}$ in $1 \times 10^{-5} \mathrm{~mol} \mathrm{~L}^{-1}$ aclonifen solution in borax buffer ( $\mathrm{pH}$ 9.2) at several scan rates. In the reverse potential sweep there was no trace of an anodic process, which demonstrated the irreversibility of electrode reactions. To explain the nature of this process, the influence of the scan rate $(v)$ on the better defined peak current (at $E_{\mathrm{p}}=-0.65 \mathrm{~V}$ ) was investigated. The relationship between the peak current and the scan rate was linear and can be illustrated with the equation $I_{\mathrm{p}}=k v^{x}(k-$ constant parameter) The values of $x$ were expected to be 0.5 and 1 for diffusion-controlled and adsorption-controlled reactions, ${ }^{25,26}$ respectively. The regression of $\log \left(I_{\mathrm{p}}\right)$ vs. $\log (v)$ gave a slope value of 0.96 (the correlation coefficient of the straight line is 0.9936), indicating that the reduction current is controlled with adsorption.

Such an electrode mechanism can be described by two equations:

$$
\begin{aligned}
& O x \rightarrow O x_{\text {ads }} \\
& O x_{\text {ads }}+n \mathrm{e}^{-} \rightarrow R e d_{\text {ads }}
\end{aligned}
$$

In 1988, Lovric et al. $^{27}$ evaluated empirical expression resulting from the reactions above:

Peak position:

$$
E_{p}-E_{0}=(R T \div \alpha n F) \ln \left(k_{0} t_{p}\right)-0.7 \Delta E
$$

The electrochemical signal of aclonifen was tested with various voltammetric techniques, such as cyclic voltammetry, linear sweep voltammetry, differential pulse voltammetry and square wave voltammetry. Thanks to the highest peak currents, the best sensitivity, and the possibility to carry out experiments at high scan rates over short analysis time, square wave voltammetry was chosen for further analytical application. In an alkaline medium, the SWV response of aclonifen (Fig. 1) exhibits two peaks at approximately $-0.65 \mathrm{~V}$ (peak 1 ) and at $-1.15 \mathrm{~V}$ (peak 2 , not shown) as in cyclic voltammetry measurements - Fig. 2. The voltammograms recorded with SWV confirm the irreversibility of the reduction reaction.

In such a case, two possible reduction pathways of the nitro group present in the aclonifen molecule should be considered. ${ }^{28-31}$ In the first pathway (Equation (4) and (5)), reversible formation of one-electron nitro radical anion is followed by irreversible three-electron reduction. As the stability of $\mathrm{ArNO}_{2}^{-}$is increased by the absence of 
free protons, this mechanism is the most common in aprotic solvents or strongly alkaline aqueous media.

$$
\begin{aligned}
& \mathrm{ArNO}_{2}+e^{-} \leftrightarrow \mathrm{ArNO}_{2}^{*} \\
& \mathrm{ArNO}_{2}^{*}+3 e^{-}+4 \mathrm{H}^{+} \rightarrow \mathrm{ArNHOH}+\mathrm{H}_{2} \mathrm{O}
\end{aligned}
$$

In the second possible pathway (Equation (6) and (7)), four-electron reduction of $\mathrm{NO}_{2}$ to $\mathrm{NHOH}$ (Equation (6)) and two-electron reduction of $\mathrm{NHOH}$ to $\mathrm{NH}_{2}$ (Equation (7)) takes place. This mechanism occurs in acidic and slightly alkaline aqueous media.

$$
\begin{aligned}
& \mathrm{ArNO}_{2}+4 e^{-}+4 \mathrm{H}^{+} \rightarrow \mathrm{ArNHOH}+\mathrm{H}_{2} \mathrm{O} \\
& \mathrm{ArNHOH}+2 e^{-}+2 \mathrm{H}^{+} \rightarrow \mathrm{ArNH}_{2}+\mathrm{H}_{2} \mathrm{O}
\end{aligned}
$$

Considering the above, it can be assumed that the voltammetric response obtained at the $\mathrm{Hg}(\mathrm{Ag}) \mathrm{FE}$ in the presence of aclonifen is the result of nitro group reduction consistent with the second presented mechanism. This is confirmed by several factors: irreversibility of the signals (both peaks), ${ }^{30,32}$ an equal number of electrons and protons involved (both peaks), and shifting of the first signal to more negative potentials with increasing $\mathrm{pH} .{ }^{29,33}$ Based on these results, we suggest the following electrode reaction pathway: the peak located at $-0.65 \mathrm{~V}$ represents the reduction of the nitro group to hydroxylamine, and the second signal at $-1.15 \mathrm{~V}$ is related to the reduction of hydroxylamine to amine (Scheme 2).<smiles>Nc1c([N+](=O)[O-])ccc(Oc2ccccc2)c1Cl</smiles><smiles>CC(C)O</smiles><smiles>Nc1ccc(Oc2ccccc2)c(Cl)c1N</smiles><smiles>Nc1c(O)ccc(Oc2ccccc2)c1Cl</smiles>

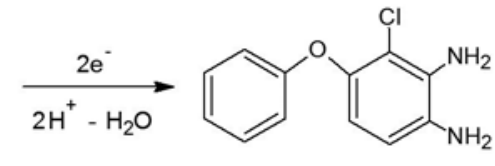

Scheme 2. Electrochemical reduction of aclonifen.

Experimental SWV parameters for the voltammetric determination of aclonifen were estimated in order to identify the conditions at which the observed maximum peak height is accompanied by the best signal shape. This optimization was performed by varying the SW frequency $(f)$, the height of SW pulses ( $\mathrm{SW}$ amplitude, $E_{\mathrm{SW}}$ ), and the step potential of the staircase waveform $(\Delta E)$ for SWV, and additionally the accumulation time and potential for SWAdSV. While adjusting SW parameters, each of them was changed with the others kept constant using $1 \times 10^{-7}$ mol L ${ }^{-1}$ aclonifen concentration. First, the SW amplitude was varied between 5 and $200 \mathrm{mV}$. A linear response of the peak current was attained up to $E_{\mathrm{SW}}=50 \mathrm{mV}$, which then stabilized, according to theory. ${ }^{27} \mathrm{SW}$ amplitude values higher than $50 \mathrm{mV}$ did not improve the sensitivity of the technique.

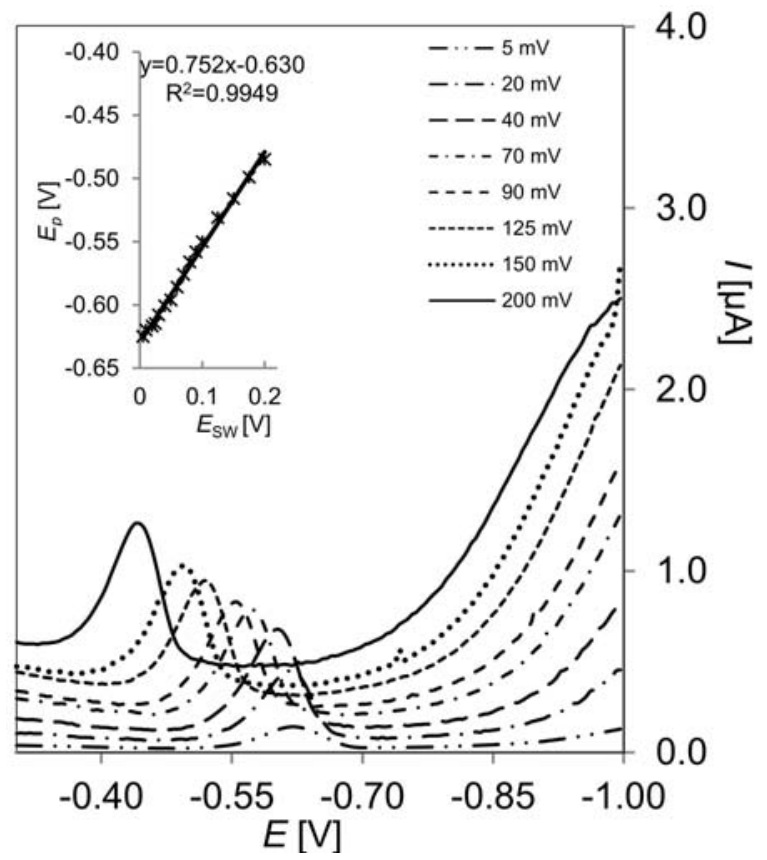

Figure 3. Effect of varying the SW amplitude on the shape and position of voltammograms obtained for $1 \times 10^{-7} \mathrm{~mol} \mathrm{~L}^{-1}$ aclonifen solution in borax buffer ( $\mathrm{pH}=9.2), f=25 \mathrm{~Hz}, \Delta E=5 \mathrm{mV}$; inset: variation of the peak potential as a function of the SW amplitude.

Furthermore, with increasing SW amplitude, the value of the peak potential shifts towards less negative values. This behavior may provide an invaluable advantage in determining aclonifen in complex matrixes. In addition, the plot $E_{\mathrm{p}}=\mathrm{f}\left(E_{\mathrm{sw}}\right)$ has a slope of 0.752 (Figure 3), which is similar to the value of 0.7 predicted by Equation (3) ${ }^{27}$ Changes in frequency $(8-1000 \mathrm{~Hz})$ influence the peak current, which is linear in the range of $8-250 \mathrm{~Hz}$. In further work, $150 \mathrm{~Hz}$ was applied. Although the use of a higher $f$ would have given a higher response, we decided against it because of the growing capacitive current and an uncompensated ohmic drop effect. ${ }^{34}$ The step potential was investigated in the range of $1-21 \mathrm{mV}$. The best response was obtained for $5 \mathrm{mV}$, while higher values of $\Delta E$ led to a poorly shaped aclonifen signal. The adsorptive properties of aclonifen at alkaline $\mathrm{pH}$ make it possible to accumulate it on the $\mathrm{Hg}(\mathrm{Ag}) \mathrm{FE}$ in a step preceding its voltammetric determination. To improve the sensitivity of the SWAdSV method, the influence of accumulation potential $\left(E_{\text {acc }}\right)$ and accumulation time $\left(t_{\text {acc }}\right)$ was studied for an aclonifen concentration of $1 \times 10^{-7} \mathrm{~mol} \mathrm{~L}^{-1}$. The effect of the accumulation potential on the stripping peak current was examined over the range $-0.5 \mathrm{~V}$ to $0.0 \mathrm{~V}$. The maximum peak current was registered for aclonifen at 
$E_{\text {acc }}=-0.2 \mathrm{~V}$. Then, the effect of $t_{\text {acc }}$ on the aclonifen peak height was checked. The optimum accumulation time to the electrode surface saturation was $45 \mathrm{~s}$. A further increase of $t_{\text {acc }}$ caused a significant drop in the voltammetric response of aclonifen. Such behavior suggests a high affinity of aclonifen molecules to the electrode surface and interaction between adsorbed molecules as well. For subsequent studies, an accumulation time of $45 \mathrm{~s}$ was chosen.
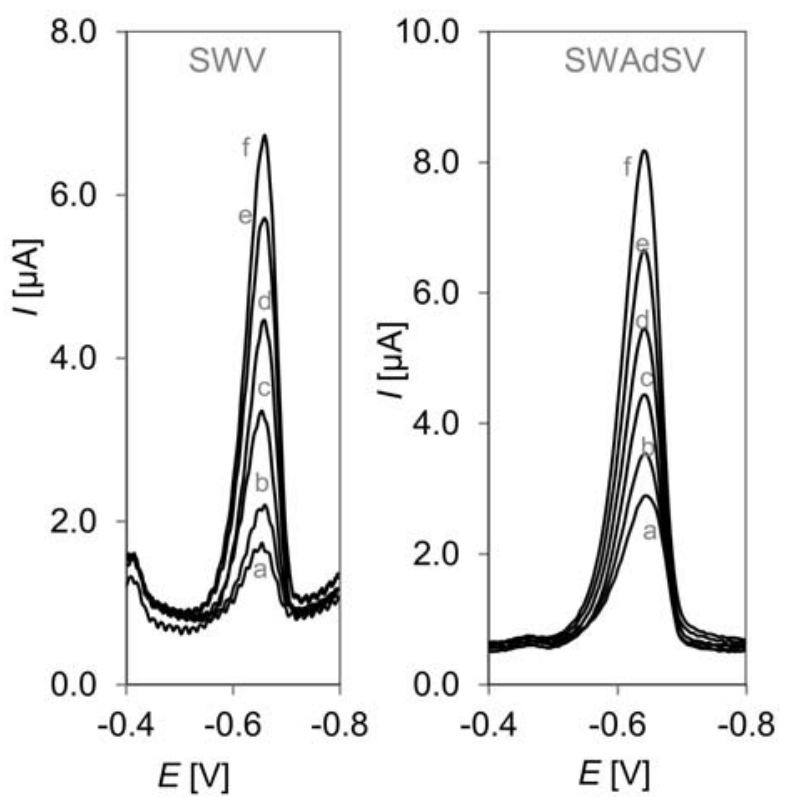

Figure 4. SW voltammograms of aclonifen in borax buffer with pH 9.2, herbicide concentrations: (a) 0.1, (b) 0.2, (c) 0.4, (d) 0.6, (e) 0.8 , (f) $1.0 \mu \mathrm{mol} \mathrm{L}^{-1}$ (SWV); (a) 0.01, (b) 0.02, (c) 0.04, (d) 0.06, (e) 0.08 , (f) $0.10 \mu \mathrm{mol} \mathrm{L}^{-1}$ (SWAdSV). The other experimental conditions were: $\mathrm{SW}$ amplitude $E_{\mathrm{sw}}=50 \mathrm{mV}$, step potential $\Delta E=5 \mathrm{~m}$ $\mathrm{V}$, and frequency $f=150 \mathrm{~Hz}$; and additionally, for SWAdSV, $t_{\mathrm{acc}}=$ $45 \mathrm{~s}$ and $E_{\text {acc }}=-0.2 \mathrm{~V}$.

\section{2. Analytical Application}

Quantitative measurements were performed using square wave voltammetry (SWV) and square wave adsorptive stripping voltammetry (SWAdSV). Due to the larger current value and a better shape, the peak at $-0.65 \mathrm{~V}$ was chosen for analytical purposes (Figure 2). The applicability of SWV and SWAdSV for the determination of aclonifen was examined as a function of its concentration in the range $1 \times 10^{-7}-1 \times 10^{-6} \mathrm{~mol} \mathrm{~L}^{-1}$ and $1 \times 10^{-8}-1 \times$ $10^{-7} \mathrm{~mol} \mathrm{~L}^{-1}$, respectively (Figure 4). Above those ranges, the decline of linearity was probably caused by aclonifen
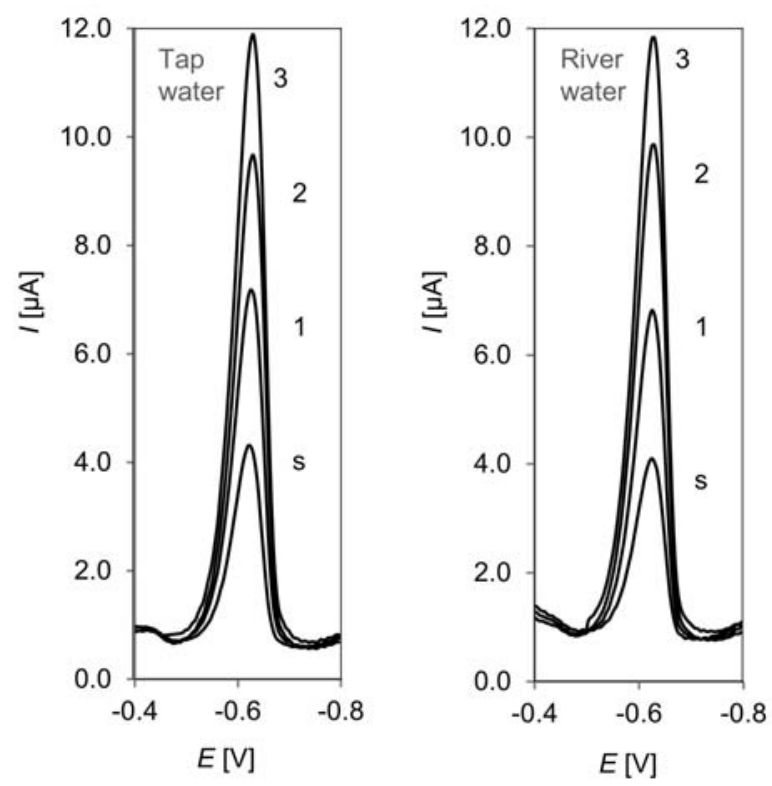

Figure 5. Voltammograms of aclonifen determination in spiked river samples using the standard addition method (s - sample; 1,2 , 3 - standard additions). Experimental conditions are the same as in Fig. 4.

Table 1. Recovery and precision of the aclonifen peak currents at various aclonifen concentrations.

\begin{tabular}{|c|c|c|c|c|}
\hline$\overline{\text { Added }\left[\mu \mathrm{mol} \mathrm{L} \mathrm{L}^{-1}\right]}$ & Found $\left[\mu \mathrm{mol} \mathrm{L} L^{-1}\right](n=6)$ & Confidence interval $^{\mathrm{a}}\left[\mu \mathrm{mol} \mathrm{L}^{-1}\right]$ & Precision RSD [\%] & Recovery $^{\mathrm{b}}[\%]$ \\
\hline \multicolumn{5}{|c|}{ SWV } \\
\hline 0.10 & 0.11 & 0.004 & 4.1 & 113 \\
\hline 0.20 & 0.20 & 0.009 & 5.6 & 99.6 \\
\hline 0.40 & 0.40 & 0.02 & 7.2 & 100 \\
\hline 0.60 & 0.57 & 0.02 & 5.6 & 94.4 \\
\hline 0.80 & 0.81 & 0.03 & 4.8 & 101 \\
\hline 1.00 & 1.01 & 0.03 & 3.4 & 101 \\
\hline \multicolumn{5}{|c|}{ SWAdSV } \\
\hline 0.0100 & 0.0098 & 0.0001 & 1.4 & 98.0 \\
\hline 0.020 & 0.020 & 0.0009 & 6.0 & 99.5 \\
\hline 0.040 & 0.042 & 0.001 & 3.1 & 105 \\
\hline 0.060 & 0.056 & 0.002 & 4.7 & 94.0 \\
\hline 0.080 & 0.080 & 0.002 & 2.3 & 99.8 \\
\hline 0.100 & 0.097 & 0.003 & 4.6 & 96.9 \\
\hline
\end{tabular}

Note: ${ }^{\mathrm{a}} \mathrm{t}\left(\mathrm{S} / \mathrm{n}^{1 / 2}\right), \mathrm{p}=95 \%, \mathrm{n}=6 ;{ }^{\mathrm{b}}$ Recovery $=100 \%+[($ Found - Added $) /$ Added $] \times 100 \%$ 
saturation on the electrode surface. The cathodic peak current increased linearly with increasing concentration of aclonifen and is expressed by the equations $I_{\mathrm{p}}(\mathrm{A})=1.5 \times$ $10^{-7}(\mathrm{~A})+5.3\left(\mathrm{~A} \mathrm{~L} \mathrm{~mol}^{-1}\right) \times c\left(\right.$ analyte, $\left.\mathrm{mol} \mathrm{L}^{-1}\right)($ correlation coefficient 0.9975$)$ and $I_{\mathrm{p}}(\mathrm{A})=6.1 \times 10^{-9}(\mathrm{~A})+57.0$ $\left(\mathrm{A} \mathrm{L} \mathrm{mol}{ }^{-1}\right) \times c$ (analyte, $\mathrm{mol} \mathrm{L}^{-1}$ ) (correlation coefficient 0.9956) for SWV and SWAdSV, respectively.

The limits of detection (LOD, $3.1 \times 10^{-8}$ and $2.9 \times$ $10^{-9} \mathrm{~mol} \mathrm{~L}^{-1}$ ) and the limits of quantification (LOQ, $1.0 \times$ $10^{-7}$ and $9.6 \times 10^{-9} \mathrm{~mol} \mathrm{~L}^{-1}$ ) of aclonifen, for SWV and SWAdSV, respectively were calculated as in the work of dos Santos and coworkers. ${ }^{35}$ The one-day repeatability of the developed method was tested with six replicate measurements for each studied aclonifen concentration. In order to check the correctness of the method, precision (RSD) and recovery were also calculated for different analyte concentrations in the linear range (Table 1).

\section{3. Analysis of Aclonifen in Spiked Environmental Samples}

The developed procedure was applied for analysis of tap and river water using standard addition method. There was no need for any evaporation, precipitation, or extraction steps prior to the herbicide assay and details are given in Section 2.3. Voltammograms obtained during the experiments are shown in Figure 5. No additional peaks were observed within the examined potential window in the studied water samples. Analyte recovery results calculated from the linear regression equations are given in Table 2. Elaborated voltammetric method of aclonifen determination can be applied for screening purposes in such environmental samples. Due to lack of general selectivity the method is not advised when more complex matrices are met.

Table 2. Quantitative assay results from aclonifen spiked water and mean recovery values.

\begin{tabular}{ccc}
\hline & Tap water & $\begin{array}{c}\text { River water } \\
\text { (Bzura) }\end{array}$ \\
\hline Concentration added $\left[\mu \mathrm{mol} \mathrm{L}^{-1}\right]$ & 0.400 & 0.400 \\
Concentration found $\left[\mu \mathrm{mol} \mathrm{L} \mathrm{L}^{-1}\right]$ & 0.408 & 0.403 \\
Correlation coefficient & 0.9997 & 1.000 \\
Precision (RSD) [\%] & 3.7 & 3.7 \\
$\quad$ Recovery [\%] & 102.5 & 102.9 \\
\hline
\end{tabular}

\section{4. Interferences}

The selectivity of the proposed method was evaluated by the addition of possible interferents, such as heavy metal cations (divalent $\mathrm{Cd}, \mathrm{Zn}, \mathrm{Pb}$ and $\mathrm{Cu}$ ) and organic compounds acting as antibodies, fungicides, and insecticides (blasticidin S, nitrothal, acibenzolar S and clothianidin). The concentration of each interferent was increased as follows: $0.01,0.05,0.1,0.25,0.5$ and 1.0 $\left(\times 10^{-6}\right) \mathrm{mol} \mathrm{L}^{-1}$. The response was compared with the result obtained for pure aclonifen solution $\left(1 \times 10^{-7} \mathrm{~mol}\right.$ $\mathrm{L}^{-1}$ ). The presence of zinc, lead and cuprum ions as well as blasticidin S and clothianidin didn't interfere with analyte voltammetric response. Cadmium ions and nitrothal precluded aclonifen determination if the ratio aclonifen/interferent was above 1:3. The presence of acibenzolar $\mathrm{S}$ rules out the aclonifen determination. These results suggest that although method is not selective, it can be used for screening purposes in rather simple environmental samples.

\section{Conclusion}

We have demonstrated that the tested herbicide is an electrochemically active compound at a renewable silver amalgam film electrode. The electrode process consists of irreversible reduction of aclonifen and is adsorption-controlled. The voltammograms consisted of two cathodic signals associated with the reduction of the nitro group and were recorded in the alkaline medium of borax buffer with $\mathrm{pH} 9.2$.

The developed electroanalytical procedure enabled aclonifen determination in the concentration range of $1 \times$ $10^{-7}-1 \times 10^{-6} \mathrm{~mol} \mathrm{~L}^{-1}$ and $1 \times 10^{-8}-1 \times 10^{-7} \mathrm{~mol} \mathrm{~L}^{-1}$ using square wave voltammetry and square wave adsorptive stripping voltammetry, respectively. The method was also applied successfully in the determination of aclonifen in spiked tap and river water samples. The presented voltammetric method of aclonifen determination can be considered as a sensitive and effective. It can serve as an alternative to expensive chromatographic methods for routine analysis of environmental samples at least for screening purposes. Moreover, despite its limited selectivity the $\mathrm{Hg}(\mathrm{Ag}) \mathrm{FE}$ can be directly applied for field analysis of environmental samples due to its mechanical stability and easy film regeneration in contrast to the classical hanging mercury drop electrode.

\section{Acknowledgements}

This work was supported by the University of Lodz, Poland under Grant for young investigators No. 545/338 and $545 / 726$.

\section{References}

1. H. Liu, W. Cai, R. Huang, H. Xia, Y. Wen, Chirality 2012, 24, 181-187. http://dx.doi.org/10.1002/chir.21981

2. J. Wang, D. Leung, W. Chow, J. Agric. Food Chem. 2010, 58, 5904-5925. http://dx.doi.org/10.1021/jf902747t

3. L. Covarelli, L. Tosi, J. Phytopath. 2006, 154, 281-285.

http://dx.doi.org/10.1111/j.1439-0434.2006.01094.x 
4. Bayer CropScience product information. Available online at http://archive.is/0A5b (assesed March 15, 2014)

5. M.Y. Graham, Plant Physiol. 2005, 139, 1784-1794. http://dx.doi.org/10.1104/pp.105.068676

6. P. Harworth, F. D. Hess, Plant Physiol. 1988, 86, 672-676. http://dx.doi.org/10.1104/pp.86.3.672

7. O. Kilinc, R. Grasset, S. Reynaud, Pestic. Biochem. Physiol. 2011, 100, 193-198.

http://dx.doi.org/10.1016/j.pestbp.2011.04.001

8. F. D. Hess, Weed Sci. 2000, 48, 160-170. http://dx.doi.org/10.1614/0043-1745(2000)048[0160: LDHAO]2.0.CO;2

9. Kemikalieinspektionen, substance information. Available online at http://apps.kemi.se/bkmregoff/bkmblad/akloni.pdf (assesed March 15, 2014)

10. Aclonifen substance information. Available online at www.bioforsk.no/ikbViewer/Content/72105/Aklonifen.pdf (assesed March 15, 2014)

11. M. Dhouib, E. Malbranque, F. Bindler, A. Lugnier, Cent. Eur. J. Public Health 1996, 4, 51-52.

12. H.-L. Sheu, Y.-H. Sung, M. B. Melwanki, S.-D. Huang, J. Sep. Sci. 2006, 29, 2647-2652. http://dx.doi.org/10.1002/jssc.200600155

13. A. Lagana, G. Fago, L. Fasciani, A. Marino, M. Mosso, Anal. Chim. Acta 2000, 414, 79-94. http://dx.doi.org/10.1016/S0003-2670(00)00813-8

14. A. Zaouak, F. Matoussi, M. Dachraoui, Int. J. Electrochem. 2011, 2011, article ID 904570. http://dx.doi.org/10.4061/2011/904570

15. R. Inam, Z. Calmak, Anal. Methods 2013, 5, 3314-3320. http://dx.doi.org/10.1039/c3ay40333e

16. V. Novotny, J. Barek, Ecol. Chem. Eng., S 2015, 22, 451458. http://dx.doi.org/10.1515/eces-2015-0026

17. B. Baś, Z. Kowalski, Electroanalysis 2002, 14, 1067-1071. http://dx.doi.org/10.1002/1521-4109(200208)14:15/ 16<1067::AID-ELAN1067>3.0.CO;2-5

18. B. Baś, Electrochem. Commun. 2008, 10, 156-160. http://dx.doi.org/10.1016/j.elecom.2007.10.024

19. R. Piech, B. Baœ, B. Paczosa-Bator, W. W. Kubiak, J. Electroanal. Chem. 2009, 633, 333-338. http://dx.doi.org/10.1016/j.jelechem.2009.06.021

20. M. Brycht, S. Skrzypek, V. Guzsvany, J. Berenji, Talanta
2013, 117, 242-249.

http://dx.doi.org/10.1016/j.talanta.2013.08.048

21. D. Guziejewski, M. Brycht, S. Skrzypek, A. Nosal-Wiercińska, W. Ciesielski, Electroanalysis 2012, 24, 2303-2308. http://dx.doi.org/10.1002/elan.201200435

22. S. Smarzewska, S. Skrzypek, W. Ciesielski, Electroanalysis 2012, 24, 1966-1972. http://dx.doi.org/10.1002/elan.201200312

23. S. Smarzewska, D. Guziejewski, M. Skowron, S. Skrzypek, W. Ciesielski, Cent. Eur. J. Chem. 2014, 12(12), 1239-1245. http://dx.doi.org/10.2478/s11532-014-0574-7

24. S. Smarzewska, R. Metelka, D. Guziejewski, M. Skowron, S. Skrzypek, M. Brycht, W. Ciesielski, Anal. Methods 2014, 6, 1884-1889. http://dx.doi.org/10.1039/c3ay42038h

25. N. Erk, Anal. Biochem. 2003, 323, 48-53. http://dx.doi.org/10.1016/j.ab.2003.08.023

26. D. K. Gosser, Cyclic voltammetry: simulation and analysis of reaction mechanisms, Wiley-VCH, New York, 1994.

27. M. Lovric, S. Komorsky-Lovric, R.W. Murray, Electrochim. Acta 1988, 33, 739-744. http://dx.doi.org/10.1016/S0013-4686(98)80002-9

28. J. A. Squella, S. Bollo, L. J. Nunez-Vergara, Curr. Org. Chem. 2005, 9, 565-581. http://dx.doi.org/10.2174/1385272053544380

29. K. Peckova, J. Barek, T. Navratil, B. Yosypchuk, J. Zima, Anal. Lett. 2009, 42, 2339-2363. http://dx.doi.org/10.1080/00032710903142442

30. A. Navalon, R. El-Khattabi, A. Gonzales-Casado, J. L. Vilchez, Microchim. Acta 1999, 130, 261-265. http://dx.doi.org/10.1007/BF01242914

31. C. Yanez, J. Pezoa, M. Rodriguez, L. J. Nunez-Vergara, J. A. Squella, J. Electrochem. Soc. 2005, 152, J46-J51. http://dx.doi.org/10.1149/1.1904983

32. G. Pezzatini, R. Guidelli, J. Electroanal. Chem. 1979, 102, 205-219. http://dx.doi.org/10.1016/S0022-0728(79)80392-7

33. E. A. Laviron, A. Vallat, R. Meunier-Prest, J. Electroanal. Chem. 1994, 379, 427-435. http://dx.doi.org/10.1016/0022-0728(94)87167-1

34. V. Mirceski, M. Lovric, J. Electroanal. Chem. 2001, 497, 114-124. http://dx.doi.org/10.1016/S0022-0728(00)00464-2

35. L. B. O. dos Santos, G. Abate, J. C. Masini, Talanta 2004, 62, 667-674. http://dx.doi.org/10.1016/j.talanta.2003.08.034

\section{Povzetek}

$\mathrm{V}$ članku je predstavljena uporaba voltametrije s kvadratnim spreminjanjem potenciala (»square wave voltammetry «, SWV) in "square wave " adsorptivne inverzne voltametrije (»square wave adsorptive stripping voltammetry «, SWAdSV) v povezavi s ciklično obnovljivo $\mathrm{Hg}$ (Ag) FE elektrodo za določanje aklonifena v obogatenih vodnih vzorcih. Izbor optimalnih eksperimentalnih pogojev je bil narejen na osnovi proučevanja vpliva frekvence SW, amplitude $\mathrm{SW}$, časa in potenciala.

Umeritvena krivulja za aklonifen je linearna v koncentracijskem območju od $1,0 \times 10^{-7}$ do $1,0 \times 10^{-6} \mathrm{~mol} \mathrm{~L}^{-1} \mathrm{za} \mathrm{SWV}^{-8}$ in od $1,0 \times 10^{-8}$ do $1.0 \times 10^{-7} \mathrm{~mol} \mathrm{~L}{ }^{-1}$ za SWAdSV. Za SWV je meja zaznave $3,1 \times 10^{-8} \mathrm{~mol} \mathrm{~L}^{-1}$, meja določitve pa 1,0 $\times 10^{-7} \mathrm{~mol} \mathrm{~L}^{-1}$, za SWAdSV pa je meja zaznave $2,9 \times 10^{-9} \mathrm{~mol} \mathrm{~L}^{-1}$, meja določitve pa $9,6 \times 10^{-9} \mathrm{~mol} \mathrm{~L}^{-1}$. Predlagana metoda je bila uspešno uporabljena za določanje aklonifena v obogatenih vodnih vzorcih in je primerna za presejalne analize, vendar je potrebno pozitivne rezultate preveriti še z bolj selektivno metodo. 